\title{
Coworking as a Career Strategy: Implications for the Work and Family Lives of University Employees
}

\author{
Stephen Sweet and Phyllis Moen
}

\begin{abstract}
This study of 276 couples compares coworking couples, which means both partners work for the same university, with noncoworking couples, those couples in which only one partner is employed at a university. Among the employees at the two universities studied, one in seven dual-earner couples cowork. These couples are more educated and are less likely to prioritize one spouses' career over that of the other, as compared to noncoworking couples. Coworking is positively associated with work commitment and family success for husbands and with family and marital satisfaction for wives, especially for couples with graduate degrees. Findings suggest that employment of spouses can be beneficial to employees and institutions.
\end{abstract}

KEY WORDS: dual careers; academic couples; work-family; career success; spillover.

Family relations are undergoing remarkable transformations as increasing numbers of couples are dual earners, with both spouses employed in the workforce. For professional couples, this often means negotiating three jobs: his work, her work, and their family/relationship (Christensen \& Gomory, 1999; Hertz, 1986; Moen, 2003). One common strategy to resolve competing career agendas is to "cowork," with both spouses taking jobs with the same employer (Moen \& Sweet, 2002). However, little is known about the use of this strategy in academia and its social-relational implications. The increasing proportion of women gaining advanced degrees makes the study of dual career academic couples a salient concern for couples seeking and obtaining advanced degrees, as well as for institutions seeking to attract and retain academic employees (Ferber \& Loeb, 1997).

In this study, we examined what happens when the boundaries between work and home become blurred, as is the case for couples who share common employers. For many dual career academic couples, structural conditions (including availability of jobs in particular areas) heighten the likelihood that both partners may find themselves employed

Stephen Sweet is Assistant Professor of Sociology at Ithaca College and received his Ph.D. in sociology from the University of New Hampshire. Phyllis Moen is the McKnight Presidential Chair in Sociology at the University of Minnesota and earned her Ph.D. in sociology from the University of Minnesota. The authors are currently writing a book on job insecurity and its impact on working families. 
at the same university, thus increasing the intersections of work and family roles. Estimates suggest that as many as $35 \%$ of male faculty members and $40 \%$ of female faculty members in the United States are married to other academics (Astin \& Milem, 1997). Given the tendency toward homogamy (in that people tend to marry people with similar levels of education), for many academics the decision to accept or retain a job at a college or university can hinge greatly on their spouses also finding career success at that same institution (Blossfeld \& Drobnic, 2001).

College and university administrators find that consideration of candidates' dual career circumstances and concerns, estimated to be a factor in one in five appointments and resignations, may increase the potential to attract and retain the most desired academics (Burke, 1988; Ferber \& Loeb, 1997; Wilson, 1996). However, only one in four American colleges and universities currently have either formal or informal policies for hiring spouses (Wolf-Wendel, Twombly, \& Rice, 2000). Even when such policies exist, typically employees or candidates at research universities, those who are in minority groups, and persons with advanced academic rank are the most apt to receive administrative support in accommodating their spouses' career goals. Institutions that have formal policies about spousal employment rarely know much about their implications as few studies have been conducted to examine outcomes on either institutional functioning or family dynamics. Few, if any, of the American colleges and universities that have dual-career policies have conducted any form of formal assessment of the effects of employing spouses (Wolf-Wendel, Twombly, \& Rice, 2000).

Given the limited understanding of the implications of working with one's spouse, we assessed in this study the frequency of coworking in two universities in upstate New York, identifying the types of couples most likely to adopt a coworking career strategy. We then investigated possible implications of coworking for relational concerns, assessing the degree to which coworking is associated with effective work and family functioning. While many types of dual-earner couples work at colleges and universities, our greatest interest is in the experiences of couples in which both partners hold graduate degrees, as this group will theoretically be the most attracted to, and benefit most from, coworking relationships in university settings.

\section{Coworking as a Career Strategy}

Little is known about the actual experiences of couples who work for the same university, outside of the fact that dual career academic 
couples face many challenges in achieving and sustaining two successful careers. McNeil and Sher (1999) documented, in stark terms, some of the problems confronting dual career academics. Their study of 620 women physicists in the United States revealed that, while most of these women are married to other scientists (68\%), their (and their spouses') needs for dual appointments have seldom been supported. When offered jobs, most of these women reported that administrators extended very little support for their spouses. When it was their spouses who were the job candidates, they themselves received little help in locating employment. Those who were not able to secure jobs for both spouses reported considerable bitterness and frustration. However, in the rare circumstance that these women physicists managed to secure employment at the same institution as their spouses, they reported positive experiences.

There is some evidence to suggest that coworking arrangements among academics can have positive effects on the quality of interpersonal relationships, as well as the quality of work. One study, for instance, examined academic couples who had formed highly productive collaborative partnerships (Creamer \& Associates, 2001). This study indicated that coworking couples are characterized by egalitarian values and conduct and that partners form highly supportive relationships on and off the job. Their collaborative relationships prosper because of similarities in interests and training, shared world views, and complementary and overlapping collegial networks. The study also suggested that collaborative partners experience enhanced career success. However, as the sample was limited to highly prolific collaborative couples, it left unexamined coworking relationships that may be less successful.

Other studies suggest a less positive dynamic resulting from coworking. One couple who worked in the same academic department, for instance, reported that their colleagues were skeptical of the degree to which the wife's work was performed independently from her husband's (Hornig, 1997). Another couple expressed dissatisfaction with the coworking arrangement, as the wife remained appointed as a temporary lecturer while the husband progressed to associate professor (Smart \& Smart, 1990). Nonetheless, coworking on the whole seems to be associated with positive outcomes for dual career academic couples (Creamer \& Associates, 2001; Ferber \& Loeb, 1997). For instance, another study of college and university faculty found no relationship between having an appointment at the same university as one's partner and productivity (Ferber \& Hoffman, 1997). This suggests that having a coworking spouse in the university neither helps, nor hinders, faculty 
in terms of publication or promotion. Less clear is how working for the same college or university may influence family relationships.

Little is known about the growing numbers of spouses working for the same organization even outside of higher education. However, in an earlier study (Moen \& Sweet, 2002) we compared coworking couples with non-coworking couples in the manufacturing and utility sectors in the United States. We found that coworking couples tend to prioritize both spouses' careers more equally, thus indicating that coworking couples tend to be more egalitarian. However, there are dynamics within academic environments that may make coworking in these organizations unique and not comparable to other industries. For example, academic appointments tend to offer flexible work-hour arrangements, something less common in the rest of the U.S. labor market. Additionally, opportunities to advance dual careers can be challenging within academic institutions (McNeil \& Sher, 1999; Wilson, 1996). Finally, the types of people attracted to and employed by colleges and universities differ by educational attainment and other important demographic characteristics, as compared to other industries and occupations.

For many coworking couples, jobs precede their relationships, as people often meet "on the job." Among academics, relationships are commonly formed in graduate schools. In either case, the overlapping of intimate and professional relationships poses potential conflicts and sources of strain. A review of studies of romances in a variety of workplaces shows highly consistent findings [even though most of the research suffers from methodological weaknesses—see Mainiero (1993)]. Research shows that workers who develop close ties often try to keep their relationships secret, feeling that the workplace culture discourages personal relationships among coworkers. Evidence suggests these relationships also commonly increase conflict between work and spouse/ partner roles. For example, Collins (1983) documented an encounter in which an executive brought his coworker/lover to a dinner meeting, a decision that resulted in clients questioning his judgement. Rapp (1992) offered similar examples of role conflicts that emerge when work and romance intersect. On the other hand, coworking can offer significant advantages to couples and organizations by enhancing roles and job performance. For example, employees who have close friendships are more likely to help each other reach work goals, share career information, and provide each other with useful feedback (Creamer \& Associates, 2001; Lobel, St. Claire, Quinn, \& Warfield, 1994). It also opens possibilities for increased collegial support for both partners through expanded and complementary social networks (Milem, Sherlin, \& Irwin, 2001). 
Journalistic inquiries into the experiences of academics who are employed in the same departments indicate strong potentials for the enhancement of work lives and career success; but joint appointments can elicit negative reaction from colleagues who raise concerns of nepotism, subversion of the open search process, and the potential of increased department conflicts should the coworking marriage fail (Wilson, 1996, 1998). Studies outside of academe indicate that coworking might foster awkward interpersonal dynamics with other workers and supervisors. One survey found that, among state, county and municipal employees, two in five agreed that "spouses employed in the same organization pose/create ethical dilemmas" (Reed \& Bruce, 1993). An early survey found that $37 \%$ of university department heads would oppose the hiring of professional couples in the same department (Pingree, Butler, Paisley, \& Hawkins, 1978).

Coworking as a dual career strategy may reflect or create distinctive dynamics for men's and women's occupational and family careers. Existing studies of dual earner couples show that traditional gender norms which support the male breadwinner and female homemaker template still hold sway. One way this is reflected in contemporary dual earner relationships is found in career prioritization, as husbands' jobs tend to be favored over wives' jobs as couples decide where and when to relocate (Bielby \& Bielby, 1992). Additionally, women as a group tend to experience greater stress and conflict in managing the intersection between work and family life (Hays, 1996; Hochschild, 1989, 1997; Shelton, 1992) and they are much more likely than men to scale back their work commitments and career aspirations in order to care for children or elderly relatives (Becker \& Moen, 1999). However, these dynamics may well be buffered by being in a coworking arrangement. One possibility is that working at the same location helps to ease the conflicts between husbands' and wives' work and family goals and obligations. And it may be easier to share domestic chores more equally.

In consideration of this literature, we hypothesized that the ability to form a coworking relationship will depend both on the resources and expectations partners have about their mutual careers and the willingness of organizations to accommodate these situations. Therefore, we hypothesized the following.

Hypothesis 1. Couples with greater human capital are more likely to leverage and sustain coworking opportunities. As such, more senior employees, as indicated by age, and couples with higher educational 
attainment will be the most likely to achieve/adopt coworking situations within a university setting.

Hypothesis 2. Among employees at universities, coworking couples are less likely than noncoworking couples to follow traditional gender norms and are less inclined to favor husbands' careers over those of wives.

Although there are contradictions in the literature concerning the impact of coworking on work and family relationships, our prior study (Moen \& Sweet, 2002) suggested that communication between work and family (theoretically enhanced by coworking situations) can facilitate work and family functioning. Given the all-consuming nature of many college and university jobs and the ways in which coworking may expand the intersection between work and family responsibilities, we expected that coworking would simultaneously increase both spouses' commitment to work as well as their successful integration of work and family life. We therefore tentatively hypothesized that:

Hypothesis 3. Coworking couples, especially those in which both partners have advanced degrees, feel greater success in their work, their family life, and in integrating both, compared to dual-earner couples not working for the same employer.

\section{Methods}

To study the effects of coworking on American couples' work and family experiences and to compare coworking couples with both partners employed at a university with other dual-earner couples with only one partner employed at a university, we analyzed quantitative data from the Cornell Ecology of Careers Study ( $N=4637$ individuals). The survey data were generated in hour-long telephone interviews with residents in upstate New York from 1998 to 2000. Among all couples selected, in $85 \%$ of the cases both partners were interviewed, enabling the identification of couple types and comparisons of husbands' and wives' experiences. During interviews, spouses reported life histories, as well as current work and family relationships. As part of the interviews, respondents also identified their employer. This sample, generated through organizational samples of exempt employees and community samples of couples from middle class neighborhoods, created a representation of dual earner couples, most of whom have one or both spouses employed in managerial or professional positions. For a detailed description of the Cornell Ecology of Careers Study and sample 
Table I

Characteristics of Coworking $(N=46)$ and Non-Coworking $(N=230)$ Husbands and Wives at Two American Universities

\begin{tabular}{lrrrrr}
\hline & \multicolumn{2}{c}{ Wives } & & \multicolumn{2}{c}{ Husbands } \\
\cline { 2 - 3 } \cline { 5 - 6 } \cline { 5 - 6 } & Non-coworking & Coworking & & Non-coworking & Coworking \\
\hline Mean age & 45.08 & $47.49^{+}$ & & 47.05 & $9.88^{+}$ \\
$(S D)$ & 8.46 & 7.60 & & 9.23 & 9.01 \\
Mean health rating & 8.18 & 8.37 & & 8.37 & 8.26 \\
$(S D)$ & 1.74 & 1.34 & & 1.31 & 1.45 \\
\% with Masters Degree+ & 44.35 & 54.35 & & 48.70 & $78.26^{* *}$ \\
\% with dependent children & 60.00 & $45.65^{*}$ & & 60.00 & $45.65^{*}$ \\
Mean salary & $38,259.63$ & $43,570.65$ & & $57,382.14$ & $61,011.11$ \\
(SD) & $22,431.09$ & $25,000.93$ & & $30,699.60$ & $31,107.31$ \\
Career priority & & & & \\
$\quad \%$ Own took priority & 19.73 & $6.52^{*}$ & & 51.54 & $45.65^{*}$ \\
\% Spouse's took priority & 47.98 & $43.48^{*}$ & & 16.30 & $15.22^{*}$ \\
\% Neither partner & 32.29 & $50.00^{*}$ & & 32.16 & $39.13^{*}$ \\
$\quad$ prioritized & & & & \\
\hline
\end{tabular}

Note. Cornell Ecology of Careers Study. Sample restricted to couples with one or both partners employed at Lake University or Upstate University.

${ }^{*} p<.05 .{ }^{* *} p<.01 .{ }^{+} p<.10$.

characteristics and measures see (Moen, Sweet, \& Townsend, 2001) and the appendix.

By examining organizational affiliations, we were able to create a sample of dual earner couples in which one or both partners were employed in one of two universities in upstate New York, "Lake University" $(N=63$ women, 63 men) and "Upstate University" $(N=118$ women, 79 men). ${ }^{1}$ Among these 276 couples, we identified 46 (17\%) as coworking, with both partners employed at the same university. Although we cannot disclose the identities of these universities, we note here that Lake University is a large campus offering a wide variety of programs. In contrast, Upstate University is smaller and offers fewer, and more specialized, degrees. Although these two institutions are not representative of the diversity of colleges and universities, they can offer insight on some of the implications coworking has for couples and their employers.

As shown in Table I, coworking couples in the two universities we studied tended to be older and more educated than dual-earner couples

\footnotetext{
${ }^{1}$ We limited our analysis to the study of dual-earner, opposite sex couples, in which at least one partner has some college education.
} 
that had only one spouse employed by the university. We found no differences in terms of health or income between members of coworking and non-coworking couples. Fewer coworking couples in this sample had a child still at home. We also noted differences in how couples had prioritized their careers. Half (50\%) of the women in coworking relationships (in comparison to almost one in three [32.2\%] non-coworking women) reported that neither their own nor their spouse's career took priority (or that they took turns). As there are important demographic differences between these groups of coworking and non-coworking partners, our models controlled for potentially spurious effects in examining both the predictors and the implications of coworking. To identify factors that potentially influence couples to adopt or sustain a coworking relationship, we developed models that include indicators of the couple's age, ${ }^{2}$ human capital (both spouses having a master's degree or higher), and institutional affiliation (Lake U. or Upstate U.). We also tested career strategies to assess whether favoring neither partner's career would predict the adoption of a coworking relationship. Multivariate models tested the impact coworking had on work and family life quality controlling for presence of dependent children, salary, age, health, and institutional affiliation.

\section{Findings}

\section{What Predicts a Coworking Career Strategy?}

To study which couples are most likely to adopt coworking career strategies, we performed a multivariate logistic regression, examining associations with educational attainment, egalitarian career strategies, age, and university affiliation. We found (consistent with Hypothesis 1) that couples in which both partners have graduate degrees are twice as likely to work for the same university, compared to couples in which only one or neither partner has a graduate degree. This suggests that human capital in the form of educational attainment may exert greater leverage in seeking or retaining jobs at the same university. For example, job applicants who are senior-level professors might be better positioned than technical support staff applicants to make sure their spouses are also hired.

\footnotetext{
${ }^{2}$ Husband's and wife's ages were strongly correlated (.86), so the mean age of husband and wife is used as an indicator.
} 


\section{Table II \\ Logistic Regression Predictions of Spouses Working for the Same University $(N=276)$}

\begin{tabular}{lccc}
\hline & $B$ & $S E$ & Odds ratio \\
\hline Both partners have graduate degrees & $0.898^{* *}$ & 0.355 & 2.454 \\
Neither spouse's career favored & $0.868^{*}$ & 0.397 & 2.382 \\
Mean age of both partners & 0.033 & 0.021 & 1.033 \\
One or both partners work for Lake U. & $1.159^{* *}$ & 1.159 & 3.187 \\
Constant & $-4.182^{* *}$ & 1.062 & \\
\hline
\end{tabular}

Note. Cornell Ecology of Careers Study. Sample restricted to couples with one or both spouses employed at either Upstate University or Lake University.

${ }^{*} p<.05 .{ }^{* *} p<.01 .{ }^{+} p<.10$.

To test whether coworking is a strategy for supporting both spouses' careers, we included in the multivariate logistic regression a variable indicating whether the husband and wife agree that their strategy was to favor neither partner's career over the other, or that partners took turns (versus not doing so). Since husbands and wives do not always agree, to qualify both husbands and wives had to report favoring neither partner's career or else that the couple had "taken turns" in determining whose career took priority. Table II shows that being in a relationship in which neither partners' career takes priority more than doubles the odds (2.382) of both spouses working for the same university, supporting our hypothesis that coworking couples tend to be less traditional in terms of favoring husbands' careers over wives'.

Finally, Table II shows that institutional affiliation predicts the likelihood of being in a coworking relationship. Specifically, employees at Lake University are three times (3.187) more likely than employees at Upstate University to also have their spouses working there. These findings support other evidence of considerable variation in the degree to which university policy and personnel support dual appointments (McNeil \& Sher, 1999; Wolf-Wendel et al., 2000). But these variations might reflect the larger opportunity structure. Lake University, a large research institution, offers a wider range of academic programs than Upstate University; thus even if formal or informal policies do not promote accommodations for spouses, the available job market may.

To summarize, we found that a number of factors predict whether dual-earner husbands and wives work at the same university or whether one spouse works elsewhere. Coworking couples tend to be more educated and are also less likely to favor husbands' careers over those 
of wives. Finally, there is a significant difference in the proportion of coworking couples in each of the two participating academic institutions in our study.

\section{Does Coworking Impede or Facilitate the Fulfillment of Work and Family Roles?}

Our review of the literature suggests that having both spouses employed at the same university might produce contradictory effects. On the one hand, it may increase the ability of employees to perform their jobs effectively as workers can more easily coordinate family obligations and potentially facilitate each other's work (Creamer \& Associates, 2001; Milem, Sherlin, \& Irwin, 2001; Wilson, 1996). On the other hand, intimate knowledge of one another's colleagues and work environment may create role conflicts and spillover that could impede job performance (Collins, 1983; Rapp, 1992; Wilson, 1998).

We examined indicators for work and family life, including work hours; perceptions of work, family, and balancing success; reports of positive and negative spillover between work and family roles; and measures of couples disagreement, family satisfaction, and marital satisfaction. Preliminary analyses indicated that coworking seldom registered as a main effect in assessing relationships with work and family life quality. However, we did find contextual effects by gender and educational attainment. In line with our interest in context, we assessed the degree to which coworking situations have contrasting relationships on work-family outcomes for couples in which both spouses have at least a master's degree (compared to couples with lower levels of human capital). These analyses tested whether the effects of coworking are more pronounced for those dual high degree couples striving to maintain joint professional careers, in comparison to those couples with lesser human capital.

Finding two jobs in the same geographical location is most problematic for those couples in which both partners hold advanced degrees; under this circumstance both partners are most apt to be concerned with developing and maintaining professional careers. Accordingly, we hypothesized that couples in which both partners hold advanced degrees and are both working for the same university will experience the most success in their work and family roles.

To test these hypotheses, we constructed models with coworking as both a main effect and in interaction with a marker for dual high degree couples (both partners hold MA or higher degree). Multivariate models 
included income (logged), health, age, and life stage. Analyses were performed with General Linear Models (means and standard errors are reported in Table III), comparing coworking (CW) and noncoworking (NCW) men and women.

As hypothesized, Table III shows that men who work in the same university as their wives tend to work the longest hours. This is especially true for when both they and their wives hold graduate degrees. On average, these men put in nearly 53 hours per week, 6 hours more than their non-coworking counterparts and nearly 8 hours more than non-coworking men in couples with less education. This finding suggests that coworking men, particularly those in highly educated couples, make the largest investment-in terms of work hours-in their jobs. However, no relationship between work hours and coworking is found for wives.

One would suspect that this heavy involvement in work by coworking men would come at a cost to their family lives. We do not find this to be the case; these men (and their wives) report no more couple conflict or dissatisfaction than the others in our sample. In fact (as shown in Table III), men in highly educated couples who are working at the same university as their wives report slightly less negative family-towork spillover. Note also that coworking women in couples with dual advanced degrees report the highest family and marital satisfaction. $R$ square values indicate that its impact tends to be modest as the model explains $19 \%$ of the variance in work hours and less for other relationships. Even so, we find little to suggest that coworking has a negative impact on family lives. On the whole, these findings indicate that coworking can be a win-win situation for both couples and for institutions employing them. Coworking appears to facilitate the management of responsibilities involved in faculty or high-level administrative positions and the maintenance of family lives and work-family integration.

\section{Discussion}

Our study focused on one small, but important, demographic group, dual-earner couples in two of the many universities in the United States. This group has experience in obtaining and maintaining successful dual careers, an issue growing numbers of couples and institutions of higher education confront. In our discussion, we highlight the implications this study has for understanding work-family relationships and for the new forms of intimacy emerging in the home and in the workplace, as well as directions for future research. 


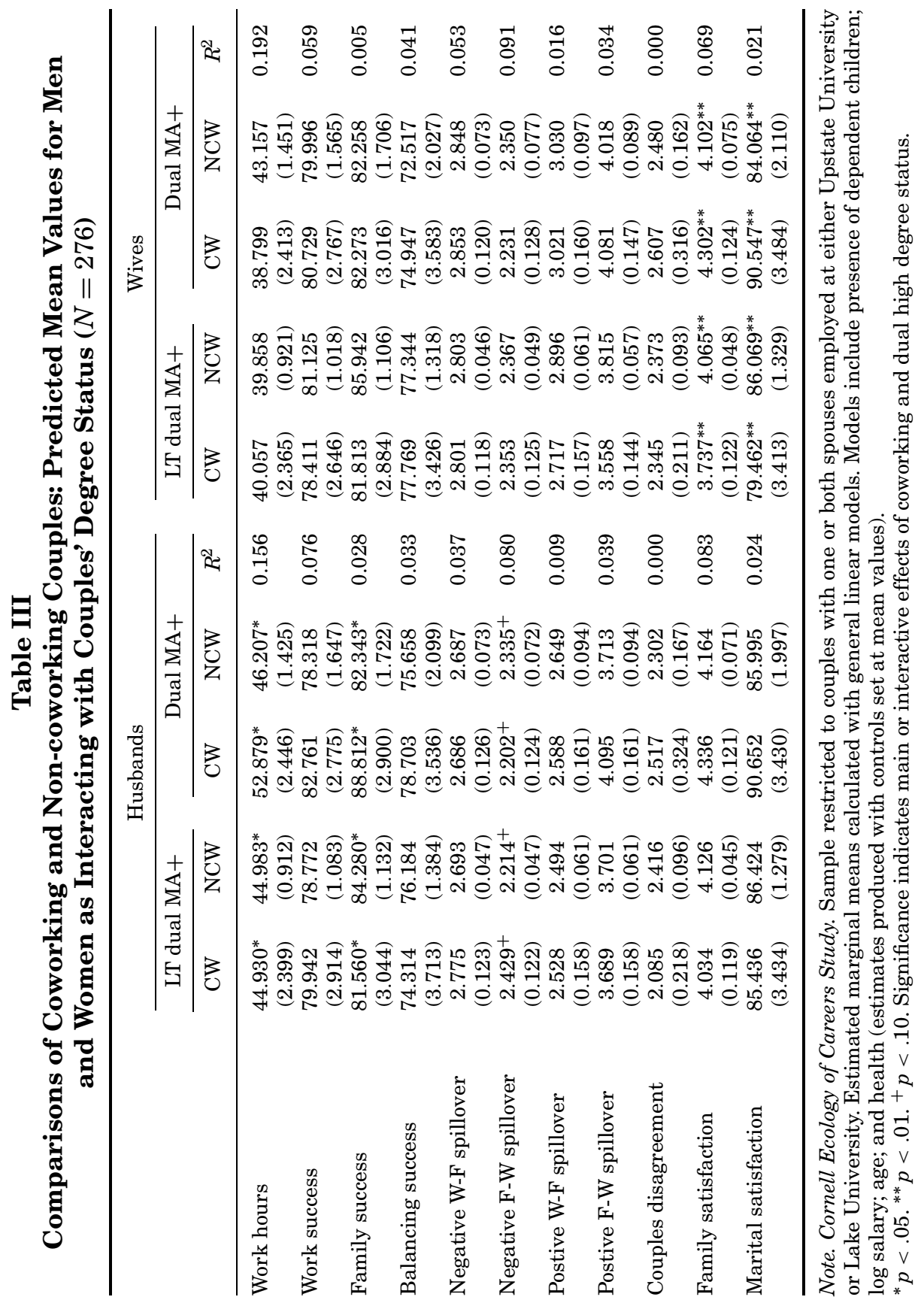


Our findings suggest positive outcomes for coworking in academic environments, a consideration that may inform efforts to shape organizational response to the employment of spouses. For men in couples with graduate degrees, coworking is positively associated with work commitment and family success; and there is less negative family-towork spillover. Coworking women in couples with advanced degrees report the highest family satisfaction and marital satisfaction.

As men and women become romantically involved in school or on the job, they create couples that want to move-or remain in their current jobs-together. We found that couples able to find or keep jobs with the same employer are more apt to place an equal priority on both partners' careers, in contrast to non-coworking couples, who tend to be more traditional in favoring husbands' careers over those of wives. It is very likely that equality in career prioritization is one of the motivations for forming and maintaining a coworking relationship.

Our findings also offer an example of a consideration important to a wider discourse on work and family, the relevancy of considering the structural connections between work and family roles and how they can create unique dynamics to facilitate work and family functioning. Recall that our literature review revealed competing theories concerning the impact of coworking relationships in academic settings. One line of thinking suggests that coworking relationships produce negative outcomes, particularly by expanding the amount of negative spillover or role conflicts between work and family domains. This approach is guided by even deeper assumptions that work and family roles inherently compete against one another. Gains at work come at costs to family. In general, our findings support a different dynamic occurring within coworking couples, pointing to positive synergy resulting from the overlapping connections between work and family lives that buffer the strains commonly experienced by dual earner couples.

It would be a misread of our findings to suggest that U.S. academic environments are entirely "family friendly" and that the only structural change needed is to increase the prospects for couples to cowork. However, enhancing employment prospects for both spouses may be a key component in creating a family friendly workplace. One of the most daunting challenges facing couples, organizations, and policy leaders is creating and supporting strategies that enable dual earner couples to manage their work and family roles. We find coworking is one such strategy adopted by couples, that appears, on the whole, to contribute to successful integration of work and family responsibilities. 
Some of the positive dynamics observed among the couples we studied may be due in part to the generally positive nature of academic life and the prospects for success among the highly educated. American institutions of higher education tend to offer higher job security and more flexible work arrangements than do other types of employers, especially for their academics on tenure tracks. One suspects that coworking for other "less hospitable" employers may undermine, rather than enhance, the quality of couples' lives. Similarly, couples with few skills to bargain with-those with low educational attainment-may gain little from coworking in two insecure jobs with similar (low) compensation. As such, the benefits we observe for coworking in academic environments may be class and occupation specific and not generalizable to other professions or social groups. We also note that our study was not able to assess the degree of closeness in the coworking arrangements or to gauge the degree to which partners collaborate, work in the same department, or work in different departments. One suspects, as the work of Creamer and associates (2001) indicated, that close collaborative ties among coworking couples can create unique, and in general, positive effects. Our findings tend to correspond with this conclusion; however, more work can be done to examine the degree to which close or distant ties in the workplace influence the coworking experience.

Given the high proportion of academics married to other academics, identifying and responding to the unique concerns facing dual career couples is one of the most important human resource concerns at colleges and universities. For dual academic couples, current experiments include joint appointments, shared positions, and the structuring of new positions to accommodate spouses, to name but a few examples (Werbel \& Hames, 1992; 1996). However, these experiments come with additional concerns relating to the fairness of favoring the candidacy of a spouse (Wexler, 1982; Wolkenbreit, 1997). For instance, policies that might favor a spouse over a non-related minority candidate may create legal problems (Shoben, 1997). However, given the current dilemmas facing dual career academics, the opposite policy, one that bars nepotism (historically common in academic departments), tends to block career pathways for women.

Most workers in the United States, as well as in other developed countries, are married to other workers; the dual-earner arrangement is the new "normal" (Blossfeld \& Drobnic, 2001). We believe that understanding the linkages between spouses, including their interlocking careers, is key to the development of workplace policies for this new workforce. Coworking is likely to become even more commonplace as dual earner 
families continue to comprise an ever greater proportion of the population. In our sample, one in six couples at two universities in upstate New York has both partners working within the same institution. We also find significant variation between the two participating universities, with employees at Lake University being much more likely to be in coworking relationships, suggesting that different institutions offer different levels of support for accommodating dual career couples. Even though our sample has limitations, primarily related to geographic locale and institutional foci, our findings offer a robust affirmation of the important finding that the coworking career strategy is quite common and can be a effective strategy used by academic couples to manage dual careers.

\section{Appendix: Variable Definitions and Survey Questions}

Work Hours "On average, how many hours a week do (did) you actually work, including any paid or unpaid extra hours that you put in beyond your official work week?" (Note: If a respondent's answer was missing, his or her spouse's estimate of the respondent's work hours was inserted.) Source: modified from National Study of the Changing Workforce (NSCW) 1997.

Success at Work Life "How successful do you feel about your work life?" On a scale of 0 to 100 , where 0 means "not successful at all" and 100 means "absolutely successful." Source: modified from NSCW 1992.

Success at Family Life "How successful to you feel about your family or personal life?" On a scale of 0 to 100 , where 0 means "not successful at all" and 100 means "absolutely successful:" Source: modified from NSCW 1992.

Couples' Disagreement "Couples sometimes have different opinions about issues in life. How much does your opinion differ from your (spouse's/partner's) on the following issues? First, what about money matters, such as how much to spend, save, or invest? What about household tasks, such as what needs doing and who does it? What about leisure time activities, such as what to do and with whom?" 1) a lot; 2) some; 3) a little; or 4) not at all. All items were reverse coded.

Marital Satisfaction "On a scale of 0 to 100 , where 0 means "not satisfied at all" and 100 means "absolutely satisfied," what number indicates how satisfied you are with your relationship/marriage?" Source: modified from NSCW 1997.

Family Satisfaction Overall satisfaction with family life was measured using the mean on five items, each of which consists of a five 
point scale. "For each statement, please indicate how well the statement describes your family, and in this case a family is defined as all individuals that live with you. 1) You are satisfied that you can turn to your family for help when something is troubling you. 2) You are satisfied with the way your family talks over things with you and shares problems with you. 3) You are satisfied that your family accepts and supports your wishes to take on new activities or directions. 4) You are satisfied with the way your family expresses affection, and responds to your emotion, such as anger, sorrow, or love. 5) You are satisfied with the way your family and you share time together." 1) never; 2) hardly ever; 3) some of the time; 4) almost always; 5) always. (alpha $=0.79$ ).

Work and Family Spillover For each of the four types of spillover, an index measure was created based on the mean response to the two individual items relating to the construct in question. This whole series of questions was introduced with, "These questions are about how your job may affect your family and personal life, and how your family and personal life may affect your job. How often have you experienced each of the following in the past year?" 1) all the time; 2) most of the time; 3 ) sometimes; 4) rarely; or 5) never. All items are reverse coded.

Negative work-to-family "Your job makes you feel too tired to do the things that need attention at home." "Job worries or problems distract you when you are at home."

Negative family-to-work "Personal or family worries and problems distract you when you are at work." "Activities and chores at home prevent you from getting the amount of sleep you need to do your job well."

Positive work-to-family "The things you do at work help you deal with personal and practical issues at home." "The things you do at work make you a more interesting person at home."

Positive family-to-work "Talking to someone at home helps you deal with problems at work." "The love and respect you get at home makes you feel confident about yourself at work."

Balancing Work and Family "How successful do you feel about balancing work and family life?" On a scale of 0 to 100 , where 0 means "not successful at all" and 100 means "absolutely successful:" Source: modified from NSCW 1992.

\section{Acknowledgment}

The authors thank Wipas Wimonsate, Veronica Banks, Deborah Harris-Abbott, and Sarah Demo for their assistance. This research was 
supported by grants from the Alfred P. Sloan Foundation (Sloan FDN \#96-6-9, \#99-6-23, and \#2002-6-8), as well as the National Institute on Aging (NIA\#2P50-AG11711-06).

\section{References}

Astin, H. S., \& Milem, J. F. (1997). The status of academic couples in U. S. institutions. In M. A. Ferber \& J. W. Loeb (Eds.), Academic couples: Problems and promises (pp. 128155). Chicago: University of Illinois.

Becker, P. E., \& Moen, P. (1999). Scaling back: Dual-earner couples' work-family strategies. Journal of Marriage and the Family, 61, 995-1007.

Bielby, W. T., \& Bielby, D. D. (1992). I will follow him: Family ties, gender-role beliefs, and reluctance to relocate for a better job. American Journal of Sociology, 97, 1241-1267.

Blossfeld, H.-P., \& Drobnic, S. (2001). Careers of couples in contemporary societies. Oxford: Oxford University Press.

Burke, D. L. (1988). A new academic marketplace. New York: Greenwood Press.

Christensen, K. E., \& Gomory, R. E. (1999, June 2). Three jobs, two people. Washington Post, A21.

Collins, E. G. C. (1983). Managers and lovers. Harvard Business Review, 61, 142-153.

Creamer, E., \& Associates (2001). Working equal: Academic couples as collaborators. New York: Routledge Falmer.

Ferber, M., \& Hoffman, E. S. (1997). Are academic partners at a disadvantage? In M. Ferber \& J. W. Loeb (Eds.), Academic couples: Problems and promises (pp. 182207). Chicago: University of Illinois Press.

Ferber, M., \& Loeb, J. W. (Eds.) (1997). Academic couples: Problems and promises. Chicago: University of Illinois Press.

Hays, S. (1996). The cultural contradictions of motherhood. New Haven, CT: Yale University Press.

Hertz, R. (1986). More equal than others: Women and men in dual-career marriages. Berkeley, CA: University of California Press.

Hochschild, A. (1989). The second shift. New York: Avon Books.

Hochschild, A. (1997). The time bind: When work becomes home and home becomes work. New York: Metropolitan Books.

Hornig, L. S. (1997). Academic couples: The view from the administration. In M. A. Ferber \& J. W. Loeb (Eds.), Academic couples: Problems and promises (pp. 248-269). Chicago: University of Illinois Press.

Lobel, S. A., St. Claire, L., Quinn R. E., \& Warfield, A. (1994). Love without sex: The impact of psychological intimacy between men and women at work. Organizational Dynamics, 23, 5-16.

Mainiero, L. A. (1993). Dangerous liasons?A review of current issues concerning male and female romantic relationships in the workplace. In E. Fagenson (Ed.), Women in management (pp. 165-185). Newbury Park, CA: Sage.

McNeil, L., \& Sher, M. (1999). Dual science career couples. Retrieved August 20, 2003, from http://physics.wm.edu/ sher/survey.pdf

Milem, J. F., Sherlin, J., \& Irwin, L. (2001). The importance of collegial networks to college and university faculty. In E. Creamer and Associates (Ed.), Working equal: Academic couples as collaborators (pp. 146-166). New York: Routledge Falmer.

Moen, P. (Ed.) (2003). It's about time. Ithaca, NY: Cornell University Press.

Moen, P., \& Sweet, S. (2002). Two careers one employer: Couples working for the same corporation. Journal of Vocational Behavior, 61, 466-483.

Moen, P., Sweet, S., \& Townsend, B. (2001). How family friendly is upstate New York? Ithaca, NY: Cornell Careers Institute. 
Pingree, S., Butler, M., Paisley, W., \& Hawkins, R. (1978). Anti-nepotism's ghost: Attitudes of administrators toward hiring professional couples. Psychology of Women Quarterly, $3(1), 22-29$.

Rapp, E. (1992, February). Dangerous liasons. Working Woman, 56-61.

Reed, C. M., \& Bruce, W. M. (1993). Dual-career couples in the public sector: A survey of personnel policies and practices. Public Personnel Management, 22, 187-199.

Shelton, B. A. (1992). Women, men and time. New York: Greenwood Press.

Shoben, E. (1997). From antinepotism rules to programs for partners: Legal issues. In M. A. Ferber \& J. W. Loeb (Eds.), Academic couples: Problems and promises (pp. 226247). Chicago: University of Chicago Press.

Smart, M. S., \& Smart, R. C. (1990). Paired prospects: Dual career couples on campus. Academe, 76, 23-27.

Werbel, J. D., \& Hames, D. S. (1992). Are two birds in the hand worth more than one in the bush: The case of paired employees. Human Resource Management Review, 2, 317-328.

Werbel, J. D., \& Hames, D. S. (1996). Anti-nepotism reconsidered: The case of husband and wife employment. Group and Organization Management, 21, 365-379.

Wexler, J. (1982). Husbands and wives: The uneasy case for antinepotism rules. Boston University Law Review, 62, 75-142.

Wilson, R. (1996, September 20). Weary of commuter marriages, More couples in academe make career sacrifices to be together. Chronicle of Higher Education, 43, A10-A13.

Wilson, R. (1998, April 17). When officemates are also roommates. Chronicle of Higher Education, 44, A12-A14.

Wolf-Wendel, L. E., Twombly, S., \& Rice, S. (2000). Dual career couples: Keeping them together. Journal of Higher Education, 71, 291-321.

Wolkenbreit, R. (1997). In order to form a more perfect union: Applying no-spouse rules to employees who meet at work. Columbia Journal of Law and Social Problems, 31, 119-165. 
Copyright of Innovative Higher Education is the property of Kluwer Academic Publishing and its content may not be copied or emailed to multiple sites or posted to a listserv without the copyright holder's express written permission. However, users may print, download, or email articles for individual use. 